\title{
Local Conceptualisation of Health, Illness and Body in Lusaka, Zambia
}

\author{
Kateřina Mildnerová \\ Katedra antropologických a historických věd Fakulty filozofické Západočeské Univerzity v Plzni, Sedláčkova 15, 306 15 Plzeň
}

LOKÁLNÍ KONCEPTUALIZACE ZDRAVÍ, NEMOCI A TĚLA V LUSACE, ZAMBIE

\begin{abstract}
ABSTRAKT Zdraví/nemoc je sociálně a kulturně konstruovaná kategorie. V Zambii je nemoc chápána komplexně, v jejím kosmologickém a sociálním rozměru. Nemoc není konceptualizována pouze jako narušení fyzické a psychické integrity člověka, ale představuje v nejširším slova smyslu neštěstí nebo smůlu, jehož př́íina má externí povahu a je spojována s konkrétní agresí a záměrem démonů, mstivých duchů nebo zlých čarodějů/nic. Místní věří, že tyto neviditelné síly prostupují celým jejich životem a významně ovlivňují zdraví, plodnost, bohatství a mezilidské vztahy. Na rozdíl od biomedicíny založené na karteziánském chápání těla a duše, chápou místní tělo a nemoc jako polysémantickou kategorii v níž jsou zahrnuty fyzické, psychické, duchovní, sociální i enviromentální aspekty. Lokální konceptualizace těla je založena na metaforickém spojení fyziologie člověka a ekologie (konkrétně ročních cyklů v př́rodě) a bere v potaz tělesnou teplotu a fluiditu tělesných tekutin. Pro obyvatele Lusaky je zdraví (stejně jako bohatství) chápáno jako kvantitativní entita, která je distribuována na principu „omezeného dobra“. Věří se, že člověk může nabýt zdraví nebo bohatství jedině „na úkor“ jiného člověka, který tím pádem onemocní nebo přijde o své jmění. Proces onemocnění a léčení je tak vzájemně propojen a ovlivňuje se.
\end{abstract}

KLÍČOVÁ SLOVA Zambie-Lusaka; zdraví; nemoc; tělo; sociální a kulturní konstrukce zdraví/nemoci; teorie horka a chladu; kulturní etiologie; posedlost duchem; čarodějnictví; magická nákaza

ABSTRACT Illness/health is socially and culturally constructed category. In Zambia, conception of illness is connected to a wider framework of religion and social reality. Illness is not seen as a mere disruption of physical and psychological integrity of an individual. It is conceived in broader terms as a sort of misfortune or bad luck caused by the intervention of different invisible powers such as spirits, demons, ghosts and witches. It is believed that the invisible powers penetrate the whole of life and significantly influence health, fertility, wealth and social relations. In contrast to biomedicine based on the Cartesian distinction of body and mind, local conception of health/illness and body draws on idea that its physical, mental, spiritual, social and environmental aspects are closely interrelated. Local conceptualisation of body proved to be based on a metaphorical linkage between the physiology of men and ecology (in particular seasonal processes in nature) and in terms of both temperature and fluidity in the body. For Lusaka dwellers health/illness is considered to be a quantitative unexpandable entity which is distributed in the world on the principle of limited good. It is believed that one can not be healed or become wealthy unless at expense of someone else. As a result the processes of healing and afflicting are interconnected and influence each other.

KEY WORDS Zambia-Lusaka; health; illness; body; social and cultural construction of health/ilness; hot and cold theory; cultural aetiology; spirit possession; witchcraft; magical contagion

\section{SOCIAL AND CULTURAL CONSTRUCTION OF ILLNESS/HEALTH IN ZAMBIA}

As it has been demonstrated by many ethnographers (Turner 1968, 1970; Evans-Pritchard 1937; Janzen 1978), Africans conceive an illness in broader terms as a sort of misfortune including bad luck in business, school or marriage, the loss of property or job, unhappy love, bad harvest or even a natural disaster. The typical feature of African indigenous healing traditions is that they are holistic in nature and draw on idea that physical, mental, spiritual, social and environmental aspects of health/ illness are closely interrelated. On the contrary, biomedicine is traditionally considered to be secular and based on the Cartesian distinction of body and mind, focused on the treatment of symptoms and syndromes without searching for an original cause of the illness. As Janzen notes, "dimen- 
sions of the illness such as anxiety, social conflict, anger, witchcraft and magic is traditionally seen as outside the western medicine range" (Janzen 1978, 250).

Although a biomedical health care is largely available and being the first medical option in more than half of the cases, local people approach it with distrust. In their opinion, biomedicine is unable to deal with the social, personal and spiritual context of illness. Its limited competence in understanding and treating the invisible powers involved in a patient's affliction was stated by $70 \%$ of respondents. ${ }^{1}$ As a belief in spiritually caused illnesses pervades the minds of all Lusaka dwellers, the option of attending traditional healers (ngangas) or Christian healers (profeti) logically prevails.

The praxis of indigenous healing has always been linked to the domain of religion. People believe that the biological and social aspects of a illness are anchored in a religious cosmology based on the interaction of visible' and 'invisible' worlds in everyday life. The idea that witches, ghosts and ancestral spirits may negatively influence one's life, cause physical harm, material damages, or social conflicts, lies in the core of both "traditional" and Christian medico-religious systems. Although the both systems share the same illness aetiology, i.e. illness caused by witchcraft or spirit possession, their conceptualisation of illness differs. Christianity as a major religious doctrine in Zambia has been implemented here since the beginning of the $20^{\text {th }}$ century. Since the 1970 s and in particular in the 1990s the Christianity has been significantly marked by the proliferation of so-called African Independent Churches $(\mathrm{AICs})^{2}$ that became part of the strengthening charismatic movement particularly within Protestantism ${ }^{3}$. A typical feature of these churches is focus on spiritual healing and religious syncretism - the local traditional customs and beliefs in dangerous ghosts (vivanda) ${ }^{4}$, ancestral spirits (mashabe) or witches ( $m$ fiti) are placed within the biblical religious framework where the Holy Spirit (Muzimu Oyera) is considered to be the only source of healing whereas other spirits are labelled as demons. To the contrary to traditional medico-religious system that recognizes ancestral spirits as a source of healing power and thus considers spirit possession as a spiritual calling, being possessed by ancestral spirits in the Christian setting means that one suffers from serious spiritual disease. Whereas Christian healers try to expulse the ancestral spirits from the body of a patient by praxis of exorcism, traditional healers insist on their identification, settling down and taking control over them in order to worship them.

\footnotetext{
1 The inquiry through questionnaires covered a sample of 57 respondents - patients of the Mutumwa church in the Kuku compound, and a sample of fifteen respondents who used traditional healers.

2 Today two main types of AICs can be encountered in the urban settings: (1) prophet-healing churches, and (2) Pentecostal churches.

3 However, there was also a significant charismatic renewal of the Roman Catholic Church in Zambia in the 1970s, embodied by Mr. Emanuel Milingo.

${ }^{4}$ vivanda (plural)/ chivanda (singular).
}

An illness and health is not only culturally conditioned but also socially constructed. An illness, as conceived by the local population, is never an individual matter. One's illness always affects all those who are part of the social network, regardless of the nature and origin of the ailment. The social relations of a patient play an essential role during the whole process of diagnosis and healing and significantly determine the patient's view of illness. The patient's kinsmen, friends and neighbours form a patient's solidarity network on one hand, and represent an active agent of the therapy on the other.

As the kinship solidarity network seems to be in decline in the contemporary Lusaka urban settings, others like neighbours, church communities and cult groups play an important role in the negotiation and maintenance of a patient's health. Using and maintaining different social solidarity networks is some of mechanisms of social reproduction ${ }^{5}$ in contemporary urban environment. The role of the sick is to a certain extend influenced by the normative order embedded in given social group (network). Consequently, each occurrence of sickness defines and mobilizes the awareness of rights and duties within a community (Janzen 1978). The health-seeking process in which the respective social body is involved is linked with cementing certain social relationships while excluding others social. This holds especially for witchcraft accusations where a latent social tension or conflict in the background of a patient's illness has to be revealed through divination and remedied in order to find harmony and peace within a community.

\subsection{Social and Cultural Construction of Illness within the Therapy Shopping Circle in Lusaka}

Medical culture ${ }^{6}$ in Lusaka is syncretic and pluralistic, characterised by the coexistence and intermingling of different therapeutic traditions such as indigenous medicine, biomedicine, and various African independent Christian healing churches. This wide assortment of available services and the possibility of free choice lead to the 'therapy shopping behaviour' of patients on one hand, and to the creativity and inventiveness of therapy providers. I use the expression 'therapy shopping' for specific Lusaka patient's pragmatic therapy-seeking behaviour and experimentation with different therapeutic options in quest for meaning of an illness. I decided to employ this metaphor for two reasons. Firstly because the 'shopping' connotes the financial transactions standing behind the therapy purchase, and secondly because the system of distribution of medical health care seems to work on the same principle as the market economy, i.e. supply and demand.

By analysing the phenomenon of "therapy shopping" I found

\footnotetext{
5 Social reproduction is a sociological term referring to processes which sustain or perpetuate characteristics of a given social structure or tradition over a period of time, it is society ability to regenerate itself (Bourdieu 1977).

${ }^{6}$ Medical culture is a complex of socio-cultural representations connected to the health /illness in a limited space (Lusaka town).
} 
out that as patient moves from one sector to another $(z u n g u$ luka) they deal with different beliefs and normative systems, whilst in each setting an illness is perceived, labelled and interpreted differently, and leads to a particular therapy. The patient's interpretation of illness is thus socially and culturally constructed through the process of therapy and changes according to the situation and medical setting in which it is embedded. As the patients circulate they receive several diagnoses. The meaning of the illness is significantly conditioned by the patient's identification with the diagnosis. The diagnosis that will be final, i.e. appropriate for him, depends on the effectiveness or ineffectiveness of the respective therapy he underwent. In this sense, my findings affirmed Whyte's (1989) argument that, the therapy itself establishes the diagnosis. As the following example will show, in different medical settings the same symptoms can lead to different interpretations of a patient's illness. However, patients do not consider these to be contradictory, but rather complementary. Consequently, they do not hesitate to undergo different treatments simultaneously. Patients tend to appropriate and creatively combine the elements from different healing systems in their lay medical knowledge.

Let me now illustrate social and cultural construction of illness through therapy shopping behaviour with example of one patient whom I met in the Mutumwa church in the Kuku compound in January 2009.7 Mr Zulu is a 40 year old man who is married and lives with his sister, wife and six children in a house in Chipata (the Eastern Province) near a farm where he is working. Mr. Zulu has suffered from an eye disease for two years. He has already tried several biomedical facilities as well as traditional healers without any success. As a result, he decided to travel $500 \mathrm{~km}$ to Lusaka to visit a specialised health clinic there. During the time of the treatment he stayed in his brother's house in the Mtendere compound in Lusaka. Although he came to Lusaka primarily to visit a recommended ophthalmologist, he did not hesitate to consult the Christian healers in the Mutumwa church in Kuku compound. He visited Mutumwa church on his sister's in-law recommendation regardless his membership in the Reformed church of Zambia. During our interview, he asked me whether I could recommend any competent and reputable traditional healers from Lusaka to him. As emerged from the conversation, Mr. Zulu was convinced that he had been bewitched by an unknown family member because he experienced heat in his body and several strange dreams. In the Mutumwa church, Mr. Zulu underwent the 'prophesying' - a divination through the Holy Spirit and he was told that he was possessed by demons and advised to undergo the cleansing procedures. The statement

\footnotetext{
${ }^{7}$ Mutumwa is a typical syncretic Christian prophet-healing church that has many branches all over the Zambia (in particular in towns). Mutumwa healers combine freely traditional methods of diagnosis and healing (analysis of dreams, use of medicinal herbs, ritual cleansing of the body, tattoos) with Christian liturgy and spiritual healing (use of Christian hymns, exorcism, blessings, praying, prophesying through the Holy Spirit).
}

from the prophets differed from the diagnosis he was given by traditional healers whom he had visited before. According to the traditional diagnosis, Mr. Zulu was bewitched, whereas the official documents from the hospital showed that he suffers from ceratitis. To my surprise, Mr. Zulu did not consider these different diagnoses as contradictory but complementary. He was using medicine for his eyes prescribed by a medical doctor, as well as traditional herbs prescribed by nganga for protection from witches. At the same time he received the blessings in the Mutumwa church and prayed several times per day in order to get rid of the demons. Mr. Zulu, after having experienced the variety of different therapeutic treatments preceded by the consultations with his family and friends, finally accepted the witchcraft diagnosis which seemed to be the most appropriate for him.

As this example showed, Mr. Zulu's 'explanatory model' (Kleinman 1980) ${ }^{8}$ which embraced a number of different interpretations of his illness was conditioned both by the opinion of his family members and his friends and by his own experience with different therapies. Mr Zulu's interpretation of his illness was interactively socially constructed in the process of therapy according to the situation and the medical setting in which it was embedded. His permanent questioning of the meaning of an illness through experimentation with different therapeutic options helped Mr. Zulu to define his final diagnosis.

\section{LOCAL CONCEPTUALISATION OF HEALTH AND ILLNESS}

\subsection{Linguistic Analysis of Medical Terms ${ }^{9}$}

When speaking about the health (omoyo), informants in Lusaka connect it to the notion of peace (mutendere). Like peace, health is considered not to be a permanent condition, but an ideal order that has to be 'fought for'. In the eyes of the local population an illness is regarded as an 'impurity' that makes the body contaminated (ukukowesha). Additionally, the local expression 'confusion' (musikonezo), or 'disorder' refers, in the same way as Doughlas's notion of 'matter out of place' (Douglas 1966), to the disruption of health, conceived as an optimal equilibrium. Consequently, the treatment is conceived as the restoration of the purity, peace or order. To express the recovery, my informants use expressions such as kubweza mutendere mu nyumba meaning 'find peace in the house', or

\footnotetext{
8 "An Explanatory model concerns etiologies, time and way of symptoms emergence, patophysiology, duration of an illness and therapy“(Kleinman 1980: 106). In this context I mean the patient's way of understanding his illness.

9 All medical terms are in a local chiNyanja language that serves as a lingua franca in Lusaka. ChiNyanja is a Bantu language based largely on Chewa (spoken in Malawi) and Nsenga containing loan words from Bemba and English.
} 
kubweza mutendere mu mutima meaning 'find peace in the heart'.

Linguistic analysis of the chiNyanja term matenda reveals that it corresponds to the biomedical notion disease in English. ${ }^{10}$ However, the term matenda is also used more broadly to refer to an affliction caused by a human, non-human or supernatural agent as shows the local term for witchcraft - matenda yakubantu - meaning a 'disease coming from people'. In order to express disease, my informants use also the term chironda. Although chironda could be translated in English as 'sore', it broadly refers to any physical disease connected to the condition of a prolonged suffering body such as AIDS. To express a condition of illness, the term kuduala meaning 'to be sick' is widely employed.

In order to describe bodily symptoms, the patients in Lusaka preferably employ a variety of metaphors. These do not reflect only on physical feelings, but also to emotional and interpersonal considerations. The following interpretation of local perceptions of illness is based on analysis of the most common metaphors employed by the patients in Lusaka. For this purpose I draw on de Sardan's interpretative method of 'semiological translation' defined as "a shift between the semiological system of informants and semilogical system of a researcher" (de Sardan 1995, 89). The semiological translation of symptoms as experienced by patient enables us to better comprehend the patient's explanatory model, i.e. how the illness is constructed from his point of view.

To illustrate the use of metaphors, let me give an example of the description of backache or headache. Although the patients are acquainted with chiNyanja expressions mutu $\mathrm{ku} \mathrm{mu-}$ sana (backache) or mutu ku wava (headache), they use more often the metaphor of heaviness instead. Having a headache, patients complained about 'feeling like carrying a heavy load' or, 'feeling as if someone was walking on them'. This metaphor can be explained by the fact that the chiNyanja term kulema means both 'heavy' and 'tired'. Furthermore, a sharp pain in the stomach is often expressed by saying 'something is eating my intestines'. As we will see in following example, the experience of dizziness is described in terms of drunkenness whereas bodily weakness is expressed in terms of laziness. The respiration troubles, experienced by the majority of patients due to high degree of car pollution in Lusaka, are commonly described by a locution 'someone or something is kneeling on my neck' or, 'someone or something is sitting on me'. The depression troubling many patients in Lusaka, in particular women, is often expressed by collocation 'thinking too much', 'having restless heart', or 'feeling to be in the bottle'.

Let me now analyse the narrative of David Chomba, a 26 year old patient of the traditional healer Lukwesa who suffers from epilepsy (a biomedical diagnosis) ${ }^{11}$ and believes he is

\footnotetext{
${ }^{10}$ A disease is a pathological condition of a part, organ, or system of an organism resulting from various causes, such as infection, genetic defect, or environmental stress, and characterized by an identifiable group of signs or symptoms (www.freedictionary.com).

${ }^{11}$ David Chomba was hospitalised in the Chainama psychiatric hos-
}

bewitched by his mother (a traditional diagnosis). When I interviewed David, he described his ailments in the following words:

"I feel like dying for some minutes without knowing [the epileptic seizure, he suffers from a blackout which lasts for several minutes], when I wake up I feel lazy [body weakness] and powerless. I feel more like drunk [dizziness], not myself (...). Sometimes I become mad just like that. I am possessed by the spirit of lion, he is fighting in me and beating all who touched me [restlessness, aggressive behaviour] (...) I feel like something is moving in my throat like a snake [respiratory problems] (...) Sometimes when I am sleeping and I feel as if someone is kneeling on my neck [respiration problems, fitful sleep], I feel like dead and than I become alive again. It is like I feel lot of air coming into the house without a person coming inside [hallucinations connected to witchcraft].”

\subsection{Distribution of Health and Illness}

Dealing with local conceptualisations of health / illness, I would like to dwell on an idea concerning the balance of 'distribution of health and illness in the world'. As I observed, Lusaka dwellers share the opinion that one can not be healed unless his illness is transferred to someone else. Consequently, an illness is regarded as the manifestation of the omnipresent evil 'circulating in the air ready to afflict anyone'. The commonly shared idea that one can become afflicted with an illness at the same time when someone else gets rid of it and recovers refers to the logic of distribution of health and illness which can be compared to the principle of balances or communicating vessels.

As I noticed during several healing sessions, a witch-finder ${ }^{12}$ employs contra-magic as a healing strategy in order to send the patient's illness back to a witch. As it turned out, reversing the charm against a sender is a prerequisite for a patient's successful recovery. This means that a patient can be gradually recovered at the same time as a witch became afflicted. To control the effectiveness of the contra-magic, some witchfinders use a special glass bottle filled with water and small wooden sticks (Fig. 1). By checking the surface of the water in the bottle, they can estimate if their procedure was effective or not. If the water surface in the bottle gradually raises it means that the witch is afflicted. When the water suddenly turns to red, it means that the witch was finally killed. As we can see, the process of healing and affliction are implicitly interconnected.

This rule does not proceed only in the case of contra magic but also in other healing practices such as cleansing procedures called kusamba. This purgatory ritual consists of 'washing out' the illness from a patient's body by means of bathing in

pital for the first time in 2007, the provisional diagnosis was seizure disorder.

${ }^{12}$ A witch-finder is a type of a traditional healer specialised in detection and destruction of witches. 


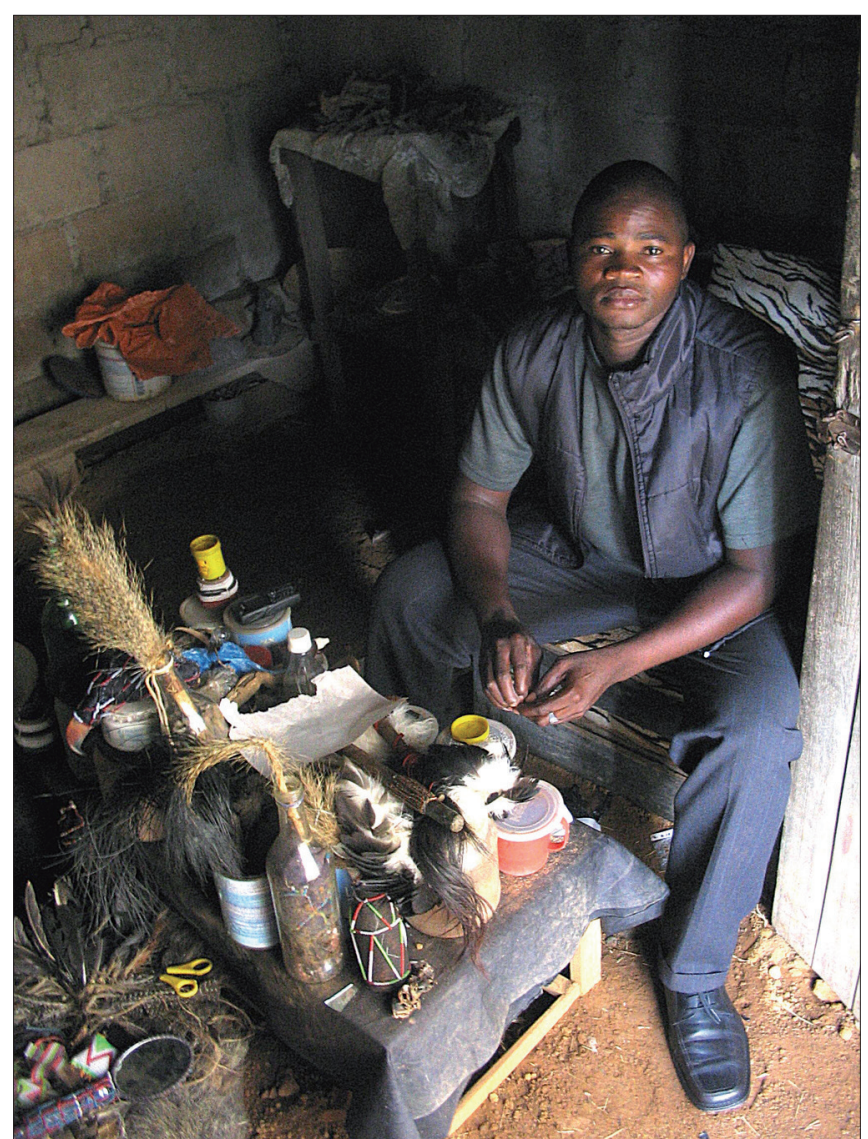

Fig. 1. Ritual paraphernalia (including magical bottles) of a witch-finder Banda Lekani from Lusaka. Photo: Kateřina Mildnerová.

a special herbal concoction. After the patient's body has been cleansed, the used concoction, as well as the patient's clothes is buried at the crossroad in the forest so that the first man who passes there becomes afflicted - 'take the reins'. As a traditional healer Vongo explained, "if you throw an illness on place where no people walk then it will not leave you. You know, the cross must be always carried by someone! Sickness is always here [pointing his finger in the air] just waiting for another one".

The logic (cognitive orientation) based on the principle of communicating vessels lies at base of the idea of witchcraft. Someone who has suddenly advanced, gained wealth, power or was promoted in work is designated as a witch in Lusaka. Through the logic of witchcraft, we cannot succeed in any other way than 'at the expense' of others. This implies the idea that the good (health, wealth and happiness) is limited in the world. This principle corresponds to the model of limited good developed by Redfield (1960) and Foster (1965). According to Foster, who deals with the nature of cognitive orientations of peasant societies and its relation to economic behaviour, "peasants view all the desired things of life, such as wealth, health, status, etc., as existing in a finite quantity and as being in short supply" (Foster 1965, 296). As the good things in life are perceived as limited quantities, people believe that if one profits in life, it must be at the expense of others.
This type of reasoning is closely connected to the local conceptualisation of a witch as someone embodying insatiable greed, acting anti-socially and driven by the desire to harm. In Lusaka, any kind of 'surpassing' such as success in work, business, school or even politics is conceptualised locally in terms of individualism and selfishness. The individualism or individual accumulation of funds is seen as threat to the collectively shared egalitarian norms of reciprocity and therefore implies the notion of witchcraft.

\subsection{Illness Aetiology}

As mentioned earlier an illness is seen as an affliction caused by the intervention of different invisible powers such as spirits, demons, ghosts and witches that are believed to penetrate the whole of life. The first task of an anthropologist concerned with study of medical culture is to find out the simplest local taxonomy of causality beliefs (Foster 1976). The causality classification I suggest here is based on my observations and interviews with different traditional healers, prophets and their patients. It corresponds to a certain measure to the central and south Bantu aetiological model proposed by other scholars such as Janzen (1978), Foster (1976) and Ooisthuizen (1989). Unlike their classification is triadic, mine includes a forth causal level, that of magical contagion.

\section{1) Illness caused by God or nature}

This comes under the category of the biomedical notion $d i$ sease to which correspond the chiNyanja term matenda. The diseases such as tuberculosis, sexual transmitted diseases (S. T. I), AIDS, malaria, diarrhoea, asthma, cancer, influenza, cholera and hepatitis are generally considered to be natural, i.e. not spiritually caused.

2) Illness caused by the magical aggression of a man

This is an aetiology associated with witchcraft (mfiti). The diagnosis of this kind of illness is generally known under term matenda yankubantu meaning 'diseases caused by people' or under the English term 'African disease'. As the etymology of English term witchcraft indicates, it is a craft skill, art or practice carried out by a witch. Furthermore this craft is based on secret knowledge of mankhwala (herbal medicine) and chizimba (animal based medicine) as well as magical incantations in order to produce a desired effect. In Lusaka it is believed, that witches are not born as such and do not posses any inner essence that gives them special power. On the contrary, a witch is someone bad, usually in the close family circle, who in a quest for revenge or desire to hurt, is driven by feelings of jealousy, envy and hate, and who intentionally procures wanga (bad charms) either by purchasing it from another witch specialist, or who is a witch specialist himself.

3) Illness caused by the mystical aggression of a spirit

It is believed that a spirit can afflict one by possessing him (kukunena), or 'hanging on him' (chivanda chamukwerera). As I observed, spirit possession as illness aetiology prevails in Lusaka (particularly in the African Christian churches). One can get possessed and therefore afflicted either by powerful 
ancestral spirits mashabe, by dangerous intrusive ghosts called vivanda, or graveyard revenants chipuku. This spirit possession can be explained in terms of a spiritual punishment for his improper behaviour, magical contamination, or witchcraft. It is believed that any possessing spirit whether ancestral, Christian or foreign announce his coming in a form of illness. The spirits can afflict a medium by an accident, or as a result of inattention. They can be also transmitted, or inherited within the family. Additionally, spirits in particular vivanda, might be intentionally manipulated by a witch and transferred to someone by means of charms. Whereas possession by chivanda is always regarded negatively, possession by ancestral mashabe spirit is interpreted as a positive sign within the traditional medico-religious system. The medium is believed to be involuntarily chosen by an ancestor who wishes to be recognised and worshipped. Traditional medicine treats the chivanda possession by means of the exorcism or body cleansing (kusamba), whereas the mashabe possession is often linked to adorcism in the Luc de Heusch's term (1962).

4) 'Illness caused by the magical contagion'

It is believed that one can get afflicted by a direct contact with an impure, spiritually dangerous entity. The notion of contagiousness in the Durkheimian (1965) sense of the term is closely linked to the transition between the domains of the sacred and profane. As it is conceptualised in the study of religion, the transition between these two domains is charged with ambiguity, endowed with both dangerous (afflicting) and potent (healing) powers. A person suddenly possessed by a spirit, bewitched by a charm, or contaminated by impurity is involuntarily involved with the sacred. As the access to the sacred is regulated by a whole system of ritual prohibitions that are needed to protect themselves from being contaminated by the sacred.

One can become magically contaminated either (1) by accident and therefore unintentionally, (2) through one's own unintentional fault, or (3) as a consequence of the infringement of taboos.

The first type of contagion can be illustrated with the example of the stepping over harmful concoction that Ooisthuizen classifies as 'an environmental hazard' (Ooisthuizen 1992). Kuponda pa wanga - stepping on a dangerous charm in a form of invisible medicinal herb - is the most common sort of magical contagion in Lusaka. The wanga (bad charm) can be buried at a crossroad, placed on the ground, in the house, or in the forest either by someone who 'had washed out his illness' through a purgatory bath prescribed by ngan$g a$. Anyway, people believe that the illness will automatically 'jump on them'.

Another example of unintentional magical contagion is kutsowela ndi wanga - 'playing with magic'. One can get afflicted unknowingly through improper manipulation with the protective medicine that had been enchanted before by someone, or if it has not been applied properly. As a result, a protective medicine turns into a dangerous wanga (charm). In both of the cases, the charm turns against the user or his relatives and afflicts them. As a doctor Kadanza, a traditional healer from
Kalingalinga compound, told me, "there are people who protect their field or relatives secretly on their own, it is better if your child is told, your wife is aware, because in the case that you die then your wife is not able to defuse that thing [charm] to stop it working (...) or maybe you just shift and somebody who buys that field will die." In this respect it is difficult to decide whether an improper manipulation with the protective medicine can be categorised as a magical contagion or witchcraft. As I noticed, many witch-finders in Lusaka are inclined to categorise protective medicines such as chibere (medicine to protect one's child), or lukanko (medicine to protect one's wife) as witchcraft.

Magical contagion as a cause of illness, or death can also come through disrespect of certain taboos concerning restrictions on touching impure persons. According to the local conceptualisations, the person is considered to be impure after having sexual intercourse, after having delivered or aborted a child, or while menstruating or mourning. There are also ritual restrictions concerning the manipulation with small children as they are considered to be especially vulnerable and can thus easily become contaminated. Lusaka dwellers share opinion that a child can become ill with respiratory problems if touched by someone who just had sexual intercourse, or that a child can be born ill or can even die if the woman who is pregnant is breastfeeding another child at the same time. This is due to the belief that a child who is breastfed sucks the life (energy) out from the one in the womb. In this respect, it is interesting to mention the folk aetiology used in Uganda to explain the kwashiorkor ${ }^{13}$ in a child recently weaned. It is believed that the unborn child is jealous of its older sibling, whom it tries to poison through the mother's milk, thereby forcing weaning (Burgess - Dean 1962, 25). The mothers must also be cautious about the removal of the umbilical cord because if after being dried, the cord drops from the right side of the child, it is believed to be impotent in future. Unless the umbilical cord is buried a child can be bewitched and cannot grow any more. Such a child stays underdeveloped and does not gain height or dies shortly after its birth. It is also believed that a man becomes mad (ofunta) if he has sexual intercourse with a woman who miscarried or delivered a dead baby without being ritually cleansed.

The collecting, storing and using of sacred traditional medicinal herbs (mankhwala) is subjected to multiple ritual restrictions (Fig. 2). In order to preserve its symbolic purity, the providers (healers) as well as users (patients) have to respect a special ritual code of behaviour when manipulating it. The symbolic purity of mankhwala is also inherently linked to its effectiveness. As one of my informants said, "medicine [medicinal herb] is sacred, because it comes from God. Our ancestors instructed us how to use it. If we do not respect their instructions, the medicine will become ineffective or even dangerous." Every ngan'ga instructs his patients to follow and respect the

\footnotetext{
${ }^{13}$ Kwashiorkor is an acute form of childhood protein-energy malnutrition characterized by irritability, anorexia, ulcerating dermatoses, and an enlarged liver with fatty infiltrates (www.wikipedia.org).
} 


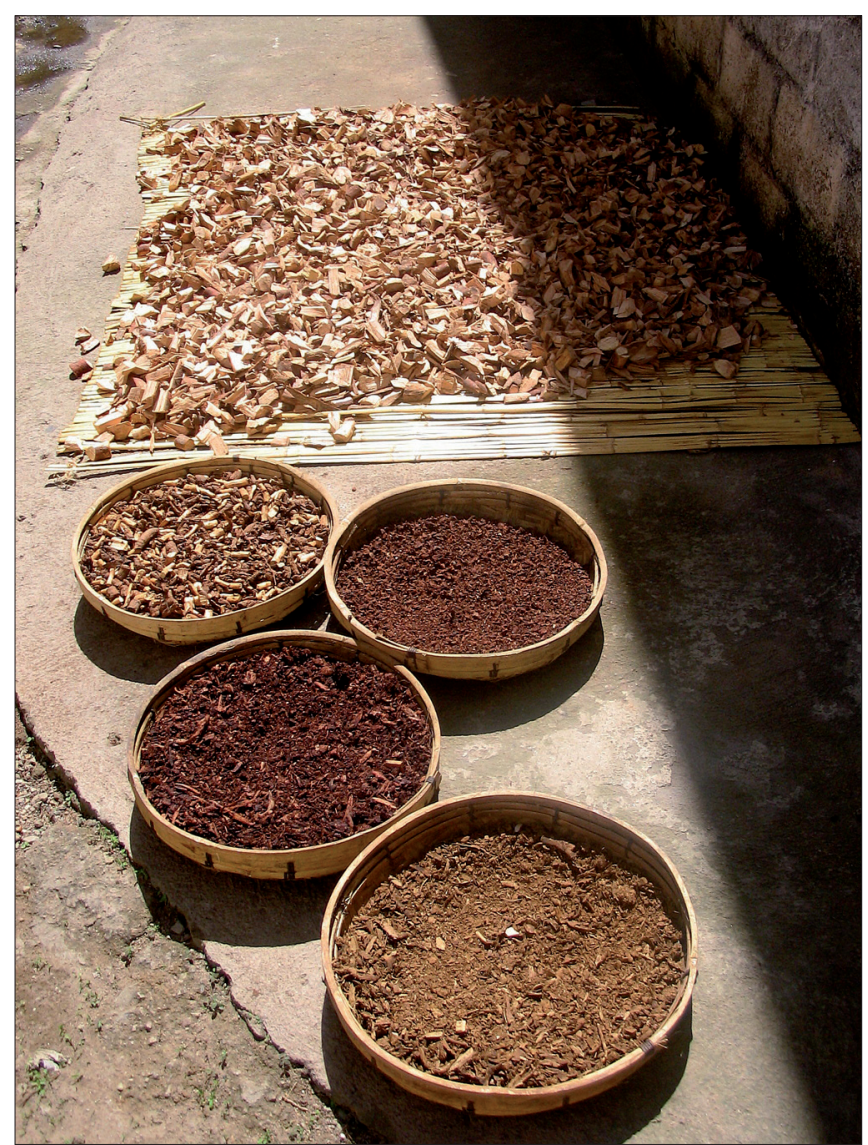

Fig. 2. Mankhwala - medicinal herbs in the form of dried bark and roots. Photo: Kateřina Mildnerová.

rules given by spirits in order to assure an effective treatment. Although the taboos differ for healers and patients, there are some, which are common for both. For instance, the ritual prohibition that mankhwala can not be touched by a menstruating woman, a woman who aborted without being cleansed, or someone who just has had sexual intercourse. Such individuals are considered impure and are thus not allowed to touch the medicine. For nganga (traditional healers) the rules are generally more complex than for patients. It is believed that they cannot touch the medicine and treat patients after someone from their family has passed away or after having had a quarrel with their spouse without having 'restored peace at home'. Another rule says that a healer when collecting the 'powerful medicine' such as mutototo (a stimulating aphrodisiac for men) cannot touch it with his right hand otherwise he becomes impotent. Healers, in particular spiritual healers and diviners, conform not only to the commonly shared ritual restrictions mentioned above, but have also to respect the special instructions revealed by their ancestral spirits. These vary according to the respective spirit.

It is important to stress that aeitiological classification suggested above is not exclusive, but rather complementary. The different causal levels often intermingle during the same process of diagnosis. For instance, diseases such as cerebral malaria or AIDS commonly considered as natural can be caused even by witchcraft. It is believed that a witch can simulate AIDS by applying the chizimba ${ }^{14}$ of chameleon so that a victim starts suffering and shrinking until he dies. Witchcraft as an advanced science can easily imitate complicated diseases such as AIDS or malaria. Witchcraft as illness aetiology can interfaces both with spirit possession - a witch is believed to use vivanda of his dead victims to bewitch other living people, or to exploit them for work in 'invisible plantations'.

\section{CONCEPTUALISATION OF THE BODY}

Illness is embedded in the personal experience of the suffering body (kuvutika). Anthropological studies treat the body as a meaningful object where "the cultural order takes shape upon the body interweaving ecology, cosmology, and physiology into a coherent whole" (Kaspin 1996, 561), or as "the social body with its boundaries" (Douglas 1970). In case of Lusaka, it is difficult if not impossible to abstract the body from the social and spiritual realm. To interpret the indigenous conceptualisations of body and bodily symptoms connected to illness, I have decided to draw on the hot and cold theor $y^{15}$ based on the assumption that one must maintain the body's internal 'temperature' balance between the opposing powers of hot and cold to insure health. This implies the avoidance of extreme or prolonged exposure of one quality or another, i.e. excessive hotness or coldness in the body refers to an illness. Consequently, the therapeutic process endeavours to restore health by re-establishing the 'temperature' balance in the body. However, in the local classifications, the hot and cold elements do not only pertain to the actual body temperature, but refer to a symbolic power contained in the diverse substances such as food, herbal medicine and human fluids. As a result, an afflicted person who experience physical changes in his body, in terms of excessive coolness, hotness, dryness or wetness endeavours to restore the proper balance in his body. In this respect, the most common therapeutic technique is the use of proper herbal medicine to withdraw excess heat or cold from the body. The local conceptualisation of health, as a proper balance between hot and cold, wet and dry elements in the body, is in its inner logic similar to the humoral theory of disease developed in the 5 century B.C. by Hippocrates ${ }^{16}$.

The hot-cold theory applied to the medical setting in Lusaka discloses that natural processes metaphorically correspond to processes in the body. My findings corresponds to a certain measure to that of Deborah Kaspin who showed in her study

\footnotetext{
${ }^{14}$ Chizimba is a medicine on animal base.

${ }^{15}$ Many anthropologists such as de Heusch 1987; Devisch 1993; Turner 1967; Comaroff 1985 dealt with the dialectics of hot and cold in the symbolism of the body.

${ }^{16}$ In the humoral theory, health is viewed as a state of balance among four humours: blood, phlegm, black bile and yellow bile. The humoral theory of disease can be found not only in Europe and Africa but also in the South America and Asia.
} 
of the Chewa cosmology of the body (1996) that human reproduction is linked to agricultural production. According to Kaspin the local conceptualisation of the body pursues two main principles: (1) fluidity and temperature that draw on the ecological and biological organisation, and (2) the principle of 'body as a map of territory' that draws on cosmological and physiological organisation. According to her interpretations, a metaphorical linkage between physiology and ecology is expressed in parallels between the seasonal processes in nature and life processes in the body. This means that coolness which is conventionally linked to water (rain) irrigating dry soil to make it fertile is metaphorically associated with the process of human reproduction. The 'cool and wet' sperm of a man is believed to fecundate a woman's womb which is metaphorically regarded as hot and dry soil, waiting to be irrigated.

The fluid such as sperm or menstrual blood that symbolises the maturity of men and women is believed to contain a vital force moyo - meaning 'life' in chiNyanja. ${ }^{17}$ It is believed that "bodily fluids generate, sustain, and invigorate life, while their diminishment leads to infertility and death" (Kaspin 1996, 569). Consequently the lack of sperm or amenorrhea is often linked to the infertility - chumba (for woman), chibola (for men). As I found out, the moyo changes within the course of life. Children and young people are considered the most vital as their blood is "quick, fresh, powerful and abundant". As a person ages, blood becomes slow, weak and dries out which leads to death. This finding is especially important when analysing witchcraft in Lusaka. Children, preferable victims of witchcraft are highly valued for their blood. As doctor Kadanza, told me, „their blood is fresh, speed and vibrant and can easily speed up the witchcraft business. The process of a growing child is linked to the business growing, that's why they [witches] prefer to do charms on children. "In Lusaka it is generally believed that witches drank the blood of their victims in order to be more powerful and strong, use the blood as a fuel for their magical aeroplanes ${ }^{18}$. A magical aeroplane (kalupe) is believed to be advanced magical technology used by 'progressive' witches to reach remote areas during a night attack. It is said to be made of a cow horn stuffed with special medicine containing human blood and meat, or from human bones, python and beads (Fig. 3). Similarly as the fluidity, coolness and

\footnotetext{
17 Other human fluids such as saliva, milk, urine are also parts of the moyo. These can be easily manipulated by witches. A widespread cautiousness about manipulation with human fluids and human waste such as hair, nails, umbilical cord, faeces etc. have been widely documented by anthropologists in the different indigenous societies even outside Africa.

${ }^{18}$ It is believed that a witch when flying, sits on the top of the magical plane, illuminates and makes a noise. "Although it looks very small, the plane had a capacity to carry as many as fifty passengers" (Times of Zambia, 01-06-2007, p. 3). I was also told that, when a witch flies over a house which is well protected with a medicine, he/she simply falls down from the plane and gets exposed all naked in front of that house, so that people can see him. It is also believed that the magical planes land on a rubbish dump and can cross large distances in a few second.
}

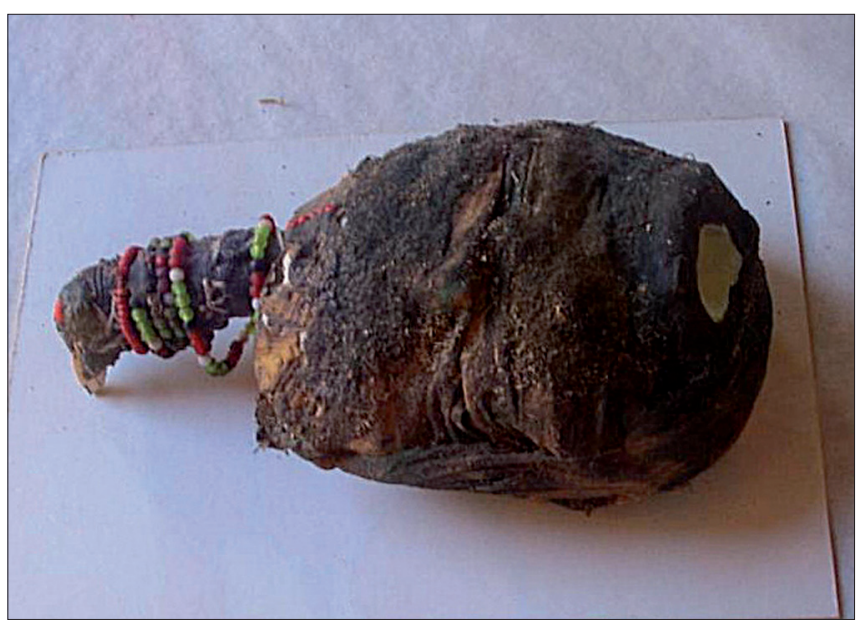

Fig. 3. Kalupe - magical aeroplane used by alleged witches in Lusaka (it becomes visible only when a witch-finder detects it and neutralises its power). Photo: Kateřina Mildnerová.

hotness also serves as measure of man's vitality. As the body acquires, shares, and loses fluids through its lifetime, it heats and cools and therefore strengthens or weakens its health. According to Kaspin, cold is linked to low sexual capacity such as of children, postmenopausal women or old men whereas hot refers to sexually active adults. As she adds, "at one extreme the corpses are cold (...) at the other extreme menstruating women are hot, as is the food they cook" (Kaspin 1996, 569). As Héritier showed in her study Symbolique de linceste et sa prohibition (1979) the symbolic logic of incest among Samos of Burkina Faso is based on binary oppositions whereas two principles are significant: the balance of oppositions and the accumulation of similarities. According to Héritier, "similarities repel and opposites attract, warmness attracts coldness and humidity "19 (Héritier 1979, 285). Her attempt was to show that the sexual taboo for men is symbolically constructed through the prohibition of having sexual intercourse with an immature girl, or with a woman in the menopause. Samo people attribute the principle of hotness to man and his sperm, as the sperm is inherently linked to blood. Consequently, procreation is perceived as the mixing of blood from two kin groups, in the sexual act of the spouses. Whereas menarcheal women are considered to be cold because they lose blood (hotness) every month, a pre-menstrual, menopausal, and pregnant woman is linked to the principle of hotness because she does not lose her blood and thus accumulates warmth.

According to the 'logic of difference and similarity', binary opposites such as hot and cold, optimally lead to equilibrium (i.e. reproduction) among Samo while the similarities lead to disruption (i.e. sterility) as the figure below demonstrates. As a result, symbolic of prohibition on having sexual intercourse with pre-menstrual or menaupausal women is constructed around the local conceptualisation of hotness and coldness of

19 "Les identiques se repoussent et les contraires s'attirent, le chaud attire le froid et l'humide" (Héritier 1979: 285). 
the body. The Samo men thus can have sexual intercourse and get married only with a menarcheal woman whereas a premestrual girl or a menopausal woman is "taboo" for them.

Man + pre-menstrual girl $=$ warm + warm $\rightarrow$ dryness $\rightarrow$ sterility

Man + menopausal woman $=$ warm + warm $\rightarrow$ dryness $\rightarrow$ sterility

Man + menarchal woman $=$ warm + cold $\rightarrow$ wetness $\rightarrow$ fertility, reproduction

In Zambia the classification of sterility and fertility is made on a similar structural principle, except that the local conceptualisation of the male-female body is reversed. A man is linked to the coldness because of the wetness of his sperm metaphorically associated with rainfalls. On the other hand, a woman symbolises dryness and warmness as she is linked to the dry hot land. According to my informants procreation is successful if this law is respected. A woman who is just having menstruation, a woman after giving birth, or one who has just aborted is considered impure and therefore dangerous for a men. She is excessively warm 'like a fire' because of her blood loosening. One of the commonly accepted ideas in Zambia is that a woman should not be wet and cold inside her vagina when having sexual intercourse with a man. Her coldness and natural wetness as well as excessive hotness are believed to be linked to sterility and death. In fact, Lusaka dwellers regard prostitutes (mahule) as infertile, because they accumulate too much wetness in the form of sperm due to regularly changing of sexual partners. As I was told, "changing sexual partners leads to infertility". I was told that due to the excessive wetness inside vagina (and womb) caused by accumulation of the sperm, the foetus can not take root there and slips out. In this way the promiscuity, as an undesirable and high risky behaviour due to H.I.V prevalence is symbolically linked to the sterility.

A woman with excessive wetness (perhaps because of gynaecological problems involved) is regarded, not only as repulsive to a man but infertile at the same time. To prevent a woman from the natural wetness occurring before sexual intercourse, a special herbal medicine called nyang'anya is prescribed by healers. "Nyang'anya makes women dry and warm so that a man can enjoy the sex (...) otherwise women which are wet and thus cold inside are like a cadaver and repeal man," said doctor Kadanza. As I noted, the traditional practise of so called 'dry sex' is widespread all over Zambia. From the biomedical point of view, this practice is considered to be highly risky because of easy HIV transmission. As a result, the health education provided by many NGO's in Lusaka is aimed at fighting against it in order to prevent the spread of AIDS. ${ }^{20}$ The demystification of the belief that 'sex with a virgin can heal AIDS' by massive health educational campaign planting billboards in Lusaka city took place five years ago and was one of the most famous and successful fights against the 'traditional prejudices' in Lusaka (Fig. 4). However, from the local point of view,

20 It is estimated that $15,2 \%$ of the total population is afflicted by HIV/AIDS(World Health Organisation 2010) whilst in Lusaka the rate is much higher.

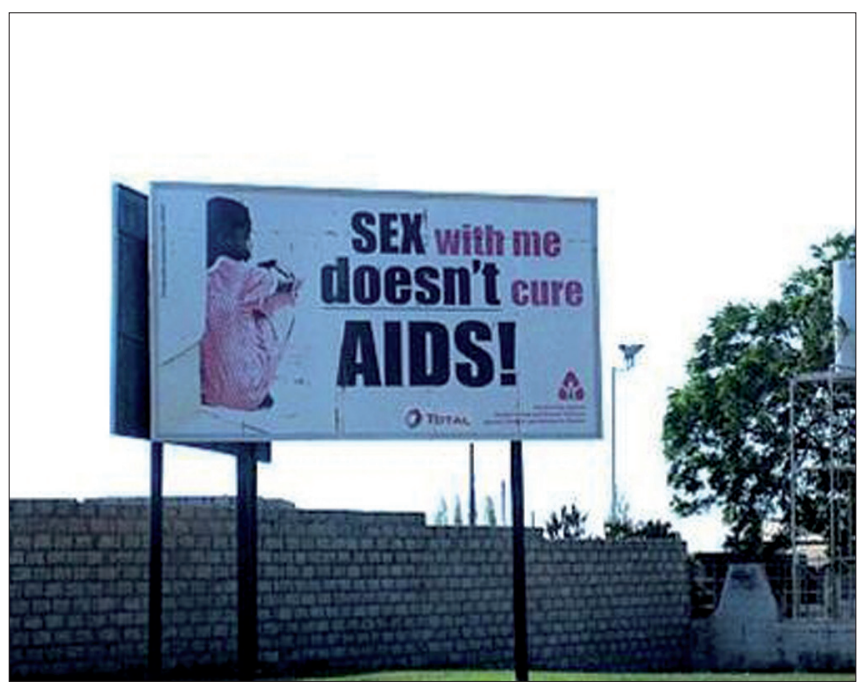

Fig. 4. Billboard confronting the 'virgin AIDS cure myth' in Lusaka city. Photo: Kateřina Mildnerová.

the abandonment of 'dry sex' would strive against the local image of successful procreation.

Another point I would like to highlight here is the local conceptualisation of excessive hotness. As it was mentioned above, excessive hotness in women is considered to be impure and generally impedes the procreation. As data obtained during my fieldwork showed, excessive hotness in both the female and male body is moreover linked to illnesses spiritually or magically caused. The wrath and anger of spirits as well as witchcraft is believed to 'heat the body' and thus bring illness. The cooling effect of water in combination with 'cold medicine' is involved in diverse purgatory rituals employed by ngangas when cleansing mourners, women after giving birth, or those afflicted with spirits, or witchcraft.

Witchcraft as a form of magical contamination of a body is generally linked to hotness, which is apparent from the use of the local expression kupya 'to be heated' as a synonym of kukulodza 'being bewitched'. In particular, hotness in one's legs is attributed to witchcraft through 'stepping on wanga' (charms used by a witch) concealed by an alleged witch in a certain place in order to afflict their victim. As one informant told me, "my feet are heated as if I was walking on live coal". Moreover, witches themselves are associated with the element of fire. I was told by witch-finders that some of the witches use fire medicine (mankhwala ku mulilo) in order to afflict their victims at a distance by means of chilubi (a voodoo doll representing the victim) burnt to ash. The ash is then mixed with other herbal medicine in order to bewitch or 'heat' a victim.

However, the excessive hotness in the body is not associated with witchcraft attacks only, but with the spirit possession as well. The local expression kubvina pa moto meaning 'dancing on fire' refers to the mashabe spirit possession - possession by ancestral spirits. I had an opportunity to assist in the ngoma mashabe ceremony ${ }^{21}$ during which the spiritual mediums

21 By undergoing the healing ritual called ngoma consisting of beat- 


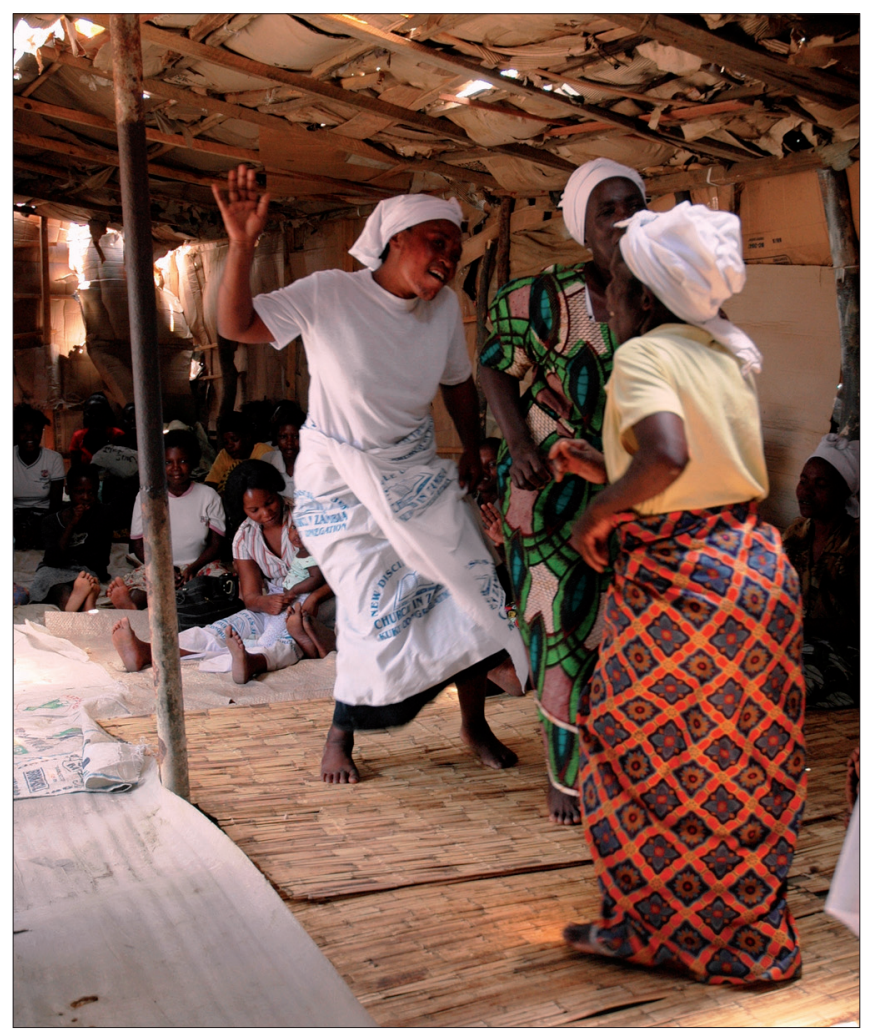

Fig. 5. Christian healers (prophets) from the Mutumwa church singing song napieyne (I am burning) during the Sunday healing session. Photo: Kateřina Mildnerová.

possessed by diverse mashabe spirits danced on live coal, exposed their body to flames, drank the hot blood of a sacrificed goat $(m b u z i),{ }^{22}$ ate live coal and smoke cigarettes ${ }^{23}$ in order to

ing drums, dancing and singing, a patient possessed by a spirit learns how to settle him down, and control the spirit in his body under the guidance of experienced mashabe healers. By establishing an intimate relationship with the spirit a patient gradually recovers from his original illness and shifts from the role of a sufferer into the role of a healer. As a result, the former afflicting spirit becomes the "healing spirit" helping a spiritual medium to heal other members of the community afflicted with the same type of spirit. Ngoma as a healing ritual represents, therefore, the initiation of a patient into the community of healers.

${ }^{22}$ The sacrifice of a goat during the ngoma initiation ceremony symbolises the death of a sufferer in exchange for the new life and identity - that of a healer.

${ }^{23}$ A possessed medium usually smokes cigarettes. This ritual behaviour occurs during the ngoma healing ceremony as well as during the individual divination séances. It is not clear, what exactly the smoking cigarettes symbolises. According to Shoko (2007) dealing with Karanga shave spirit possession in Zimbabwe, the spirit mediums smoke cigarettes and drink tea (or beer) to imitate the European way of life. When asked, spiritual healers in Lusaka claimed that mashabe ancestral spirits like smoking because they did it when they lived. It seems probable to me that smoking cigarettes in the past was not as negatively perceived as nowadays when the overwhelming majority of Zambians do not smoke because they consider smoking sinful and unhealthy. The ritual smoking of cigarettes may also refer to the demonstrate the presence and strength or the mashabe spirit entering in their body. The attributes of hotness are thus associated with spirits who are considered to be dangerous (afflicting). A medium afflicted with the spirit has to undergo the ngoma ritual in order 'to calm down' or 'cool' the spirit. As I found out, the 'coolness' is used as a synonym of calmness and peace and refers to the practice of settling down the ancestral spirit (mashabe) in a spirit medium.

Similarly, the healers from the Mutumwa church in order to demonstrate the presence of the Holy Spirit in their bodies employed the metaphors of hotness in their songs. The song napieyne 'I am burning' which was sung several times during the healing session in the church should, according to my informants help to induce prophet's the Holy Spirit possession so indispensable for healing the patients. Singing of this song is usually accompanied by agile dancing on tiptoes as if one tries to walk on live coal (Fig. 5).

\section{REFERENCES}

Augé, Marc - Zémpleni, Andras (1984): Le sens du mal. Paris: Editions des archives contemporaines

Berger, Peter L. - Luckmann, Thomas (1966): The Social Construction of Reality: A Treatise in the Sociology of Knowledge. Garden City, NY: Anchor Books.

Bourdieu, Pierre (1977): Cultural Reproduction and Social Reproduction. In Karabel, J. - Halsey, A. H., eds., Power and Ideology in Education. New York: Oxford University Press, pp. 487-511.

Buchner, Hartmut (1980): Spirits and Power: an Analysis of Shona Cosmology. Cape Town: Oxford University Press.

Burgess, Anne - Dean, R. F. A. (1962): Malnutrition and Food Habits. London: Tavistock Publications.

Comaroff, Jean (1985): Body of Power, Spirit of Resistance: The Culture and History of a South African People. Chicago: University of Chicago Press.

Evans-Pritchard, Edward Evan (1937): Witchcraft, Oracles and Magic among the Azande. Oxford: Oxford University Press.

Chabal, Patrick (2009): Africa. The Politics of Suffering and Smiling. South Africa: University of KwaZulu: Natal Press.

Cheyeka, Austin (2008): Towards a History of Charismatic Churches in Post-colonial Zambia. In: Gewald, Jan Bart - Hinfelaar, Marja - Macola, Giacomo, eds., One Zambia, Many Histories. Towards a History of Postcolonial Zambia. Leiden: Brill, pp. 144-163.

de Heusch, Luc (1987): Heat, Physiology and Cosmology: Rites de Passage among the Thonga. In: Karp, Ivan - Bird, Charles S., eds., Explorations in African Systems of Thought. Washington, DC: Smithsonian, pp. 27-43.

de Sardan, Olivier Jean-Pierre (1995): La politique du terrain. Sur la production des données en anthropologie. Les terrains de lenquête, 1, pp. 71-109.

Devisch, René (1993): Weaving the Threads of Life: The Khita Gyn-Eco-Logical Healing Cult among the Yaka. Chicago: University of Chicago Press.

Douglas, Mary (1966): Purity and Danger: An Analysis of the Concepts of Pollution and Taboo. London: Routledge \& Kegan Paul.

symbolic therapeutic value attributed to smoking itself. It is believed that by smoking one can 'call and bring' whatever is asked for. Finally, the ritual smoking of cigarettes may refer to the symbolism of hotness in the body of possessed mediums and thus represents another 'hot element' involved in ritual settings of mashabe healing ceremony. 
Douglas, Mary (1970): Natural Symbols: Explorations in Cosmology. London: Barrie \& Rockliff.

Durkheim, Emil (1965): The Elementary Forms of the Religious Life. New York: Free Press.

Fassin, Didier (1992): Pouvoir et maladie en Afrique. Paris: Presses Universitaires de France.

Foster, M. George (1965): Peasant society and the image of limited good. American Anthropologist, 67, pp. 293-315.

Foster, M. George. (1976): Disease Aetiologies in Non-Western Medical Systems. American Anthropologist, 78 (4), pp. 773-782.

Frankenberg, Ronald (1969): Man, Society and Health: Towards the Definition of the Role of Sociology in the Development of Zambian Medicine. African Social Research, 8, pp. 573-587.

Frankenberg, Ronald - Leeson, Joyce (1976): Disease and Sickness: Social Aspects of the Choice of Healers in Lusaka Suburbs. In: Loudon J. B., ed., Social Anthropology and Medicine. New York: Academic Press, pp. 573-587.

Good, Bart (1977): The Heart of What's the Matter. The Semantics of Illness in Iran. Culture, Medicine and Psychiatry, 1, pp. 25-55.

Héritier, Françoise (1979): Symbolique de linceste et sa prohibition. In: Izard, Michel - Smith, Pierre, eds., La fonction symbolique. Paris: Gallimard, pp. $209-243$.

Héritier, Françoise (1985): Le sperme et le sang. Nouvelle Revue de Psychanalyse, 32, pp. 111-122.

Janzen, John M. (1981): The Quest for Therapy in Lower Zaire. Berkeley: University of California Press.

Janzen, John M. (1992): Ngoma: Discourses of Healing in Central and Southern Africa. Berkley: University of California Press.

Jules-Rosette, Bennetta (1981): Symbols of Change. Urban Transition in Urban Community. London: Ablex.

Kaspin, Deborah (1996): A Chewa Cosmology of the Body. American Ethnologist, 23 (3), pp. 561-578.

Kleinman, Arthur (1980): Patients and Healers in the Context of Culture. An Exploration of the Boarders between Anthropology, Medicine and Psychiatry. Berkeley: University of California Press.

Laplantine, François (1993). Anthropologie de la maladie. Paris: Payot.

Last, Murray - Chavunduka, G. L. (1986): The Professionalisation of African Medicine. Manchester: Manchester University Press and International African Institute.

Logan, Michael H. (1975): Selected References on the Hot-Cold Theory of Disease. Medical Anthropology Newsletter, 6 (2), pp. 8-14.

Marwick, Max (1965): Sorcery in its Social Setting: A Study of the Northern Rhodesian Chewa. Manchester: Manchester University Press.

Ooisthuizen, Gerhardus Cornelis (1991): Indigenous Healing within the Context of the African Independent Churches. In: Ooisthuizen Gerhardus Cornelis, ed., Afro-Christian Religion and Healing in Southern Africa. New York: The Edwin Mellen Press, pp. 73-90.

Oosthuizen, Gerhardus Cornelis (1992): The Healer-Prophet in Afro-Christian Churches. Leiden: E. J. Brill.

Redfield, Robert (1960): The Little Community and Peasant Society and Culture. Chicago, University of Chicago Press.

Shoko, Tabona (2007): Karanga Religious Perception of Health and Wellbeing. Journal for the Study of Religion, 20 (1), pp. 31-41.

Sindzingre, Nicole, and Zempléni, Andras (1981): Modele et pragmatique activation et répétition. Réflexion sur la causalité de la maladie chez les Senoufo de Côte d'Ivoire. Social Science Medicine, 15, pp. 279-293.

Sindzingre, Nicole (1995): The Anthropology of Misfortune and Cognitive Science. Examples from the Ivory Coast Senufo. Science in Context, 8, pp. 509-529.

Turner, Victor W. (1970): The Forest of Symbols: Aspects of Ndembu Ritual. Ithaca, N.Y.: Cornell University Press.

van Binsbergen, Wim (2006): Religious Change in Zambia. In: Morris, Bri- an, ed., Religion and Anthropology. A Critical Introduction. Cambridge: Cambridge University Press, pp. 164-177.

van Gennep, Arnold (1997): Přechodové rituály. Praha: Nakladatelství Lidové noviny.

Westerlund, David (1989): Pluralism and Change. A Comparative and Historical Approach to African Disease Aetiologies. In: Jacobson-Widding, Anita - Westerlund, David, eds., Culture, Experience and Pluralism. Es says on African Ideas of Illness and Healing. Uppsala: Department of Cultural Anthropology, pp. 177-218.

Whyte, Susan Reynold (1989): Anthropological Approaches to African Misfortune. From Religion to Medicine. In: Jacobson-Widding, Anita - Westerlund, David, eds., Culture, Experience and Pluralism. Essays on African Ideas of Illness and Healing. Uppsala: Department of Cultural Anthropology, pp. 289-301.

Young, Allan (1982): Anthropologies of Illness and Sickness. Annual Review of Anthropology, 11, pp. 257-289.

Zempléni, Andras (1982): Ancien et nouveaux usages sociaux de la maladie en Afrique. Archives des science socials des religions, 54 (1), pp. 5-19.

\section{AUTHOR}

Mildnerová, Kateřina (30. 10. 1978, Hranice), Czech africanist, social and cultural anthropologist, recent graduate of Ph.D. studies of ethnology at the Department of Anthropology and History of the Faculty of Arts at the University of West Bohemia in Pilsen where she actually works as a research fellow. Domains of her long-term professional interest are anthropology of religion and art, and medical anthropology. She pays a special attention to the phenomenon of witchcraft in contemporary Subsaharan Africa, African Independent Churches in urban settings, transformations of indigenous healing in contemporary Zambia and religion vodun and art in Benin. During her lectures about African art and religion, she employes her knowledge from the history of Subsaharan Africa, cultural and social anthropology and history of Christianity and integrates it into a comprehensive whole. The author studied and carried out several professional traineeship in France (Centre d'études des mondes africains en Aix-en-Provence; Musée Africain à Lyon, lUniversité de Lyon II). In 2008, 2009 she effectuated an ethnographic fieldwork on spiritual healing and witchcraft in Lusaka, Zambia. She presents results of her research on international conferences and continuously publishes articles and essaies on the above mentioned topics. Currently, she prepares two monographies Witchcraft in Zambia (2011) and Religion and Art of Benin (2011). The author is a co-founder and member of the regional Cultura Africa organisation and the international organisation NYRA (Network of Young Researcher in Africa). Since 2006 she has acted as a co-organiser of Viva Africa International Conference on African Studies which is held annually by the University of West Bohemia in Pilsen and the University of Hradec Králové. Master thesis: Traditional religion vodun in Benin (2005, in Czech); Ph.D. thesis: Spiritual Healing and Witchcraft in Lusaka (2010, in English).

Contact: Mgr. Kateřina Mildnerová, Ph.D., Department of Anthropology and History of the Faculty of Art at the University of West Bohemia in Pilsen, Sedláčkova 15, 30615 Plzen, e-mail: k.mildnerova@ seznam.cz. 